\title{
STRATHCLYDE
}

DISCUSSION PAPERS IN ECONOMICS

\section{INTERNATIONAL AID TO TANZANIA - WITH SOME COMPARISONS FROM GHANA AND UGANDA}

BY

MICHAEL TRIBE

No $15-03$

DEPARTMENT OF ECONOMICS

UNIVERSITY OF STRATHCLYDE

GLASGOW 


\title{
International Aid to Tanzania - with some comparisons from Ghana and Uganda
}

\author{
Michael Tribe ${ }^{1}$
}

\begin{abstract}
This paper has three principal objectives. First, to review the level of Official Development Assistance (ODA) to Tanzania over the last two to three decades, and to place this into an economic context. This review includes some comparisons with the experience of Ghana and Uganda. Second, to discuss three major issues for the Tanzanian aid: the position of ODA as budget support, corruption, and alignment with the principles of the Paris Declaration on Aid Effectiveness. Third, to review the literature on the Tanzanian aid experience, including a range of official evaluation reports produced by the Tanzanian government and by the donor community.

The conclusions, broadly, are that ODA has been at a sustained high level for most of the period reviewed, funding a significant amount of government development expenditure, and that economic growth has been strong, with poverty reduction 'flat-lining' in Tanzania but being significant in Ghana and Uganda. Experience with budget support in Tanzania has been mixed, corruption continues as a major concern, and improvements to public finance management have been difficult to achieve. In this context governance adjustments come slowly, requiring patience on the part of both recipient governments and the ODA donor community.
\end{abstract}

Keywords: Economic Development; Foreign Aid; Development Planning and Policy; Institutions and Growth; Sub-Saharan Africa

JEL Codes: 01, 019, 02, 043, 055

* This paper is a draft version of a chapter to be included in a book based on the proceedings of a conference on Tanzanian Development held at the University of Bradford on May $29^{\text {th }}$ and $30^{\text {th }} 2014$. The book is being edited by Dr David Potts of the Bradford International Development Centre, University of Bradford. 


\section{International Aid to Tanzania - with some comparisons from Ghana and Uganda}

\section{Michael Tribe}

\section{1 - Introduction}

This paper has three principal objectives. First, it will aim to assess a range of statistical data relating to international aid (Official Development Assistance - ODA) to Tanzania (including comparisons with Ghana and Uganda) over the period from 1980 to 2012. Second, it will consider the implications of some issues arising from these ODA statistics. Finally, it will review the literature, including official publications, relating to the Tanzanian 'aid experience'.

Section 2 sets out ODA and related statistics for Tanzania, Ghana and Uganda. Section 3 extends these statistics to cover economic growth and poverty reduction. Section 4 considers a number of Tanzanian 'aid issues', including Budget Support, corruption and alignment with the principles of the Paris Declaration. Section 5 summarises findings from some of the literature on Tanzanian aid and also summarises key points from official government publications. The final section concludes.

\section{2 - Aid to Tanzania, Ghana and Uganda}

Table 1 - Recent Comparative Aid Statistics - Tanzania, Ghana and Uganda

\begin{tabular}{|l|ccc|ccc|ccc|}
\hline & 2010 & 2011 & 2012 & 2010 & 2011 & 2012 & 2010 & 2011 & 2012 \\
\hline & \multicolumn{3}{|c|}{ Tanzania } & \multicolumn{3}{c|}{ Ghana } & \multicolumn{3}{c|}{ Uganda } \\
\hline $\begin{array}{l}\text { Net ODA (US\$ m - } \\
\text { lurrent prices)) } \\
\text { Bilateral Share (\%) }\end{array}$ & 2,958 & 2,446 & 2,832 & 1,693 & 1,810 & 1,808 & 1,723 & 1,578 & 1,655 \\
Net ODA / GNI (\%) & 56 & 68 & 63 & 53 & 49 & 48 & 60 & 62 & 56 \\
Population (m) & 13.1 & 10.4 & 10.1 & 5.3 & 4.8 & 4.7 & 10.9 & 10.1 & 9.9 \\
GNI per capita (Atlas & 55.0 & 46.4 & 47.8 & 24.3 & 24.8 & 25.4 & 34.0 & 35.1 & 36.3 \\
US\$ - current prices) & 530 & 540 & 570 & 1,260 & 1,410 & 1,550 & 460 & 470 & 440 \\
\hline
\end{tabular}

Source: OECD DAC, 2014a.

Table 1 shows summary data from the OECD DAC's website (OECD DAC, 2014) for the years 2010 to 2012. In current US\$ prices it can be seen that Tanzania's per capita Gross National Income (GNI) has recently been about 20 percent higher than that of Uganda, and that Ghana has a per capita GNI about $2 \frac{1}{2}$ to 3 times that of Tanzania and Uganda. ${ }^{2}$ Despite this relative GNI per capita data it can also be seen that ODA has been running consistently higher in Ghana than in Uganda, and that ODA to Tanzania has been around 50 percent higher than to Ghana and Uganda over this period. ODA as a proportion of GNI for Tanzania over this period was about the same as that to Uganda at around 10 percent, about twice that for Ghana. ${ }^{3}$ The recent lower proportional international allocation of ODA to Ghana 
reflects the higher per capita income as compared with the two East African countries. A particularly interesting aspect of the data in Table 1 is that the bilateral share of ODA has ranged from a low of 48 percent (Ghana for 2012) to a high of 68 percent (Tanzania for 2011) illustrating the significance of multilateral ODA in recent years (coincidentally demonstrating the limitations of ODA data which includes only bilateral aid).

Table 2 - Major Donors to Tanzania, Ghana and Uganda - 2011-12 average US\$ m (current prices)

\begin{tabular}{lccc}
\hline & Tanzania & Ghana & Uganda \\
\hline USA & 555 & 268 & 396 \\
IDA & 404 & 401 & 188 \\
UK & 224 & 129 & 149 \\
AfDF & 146 & 171 & 144 \\
EU Institutions & 145 & 89 & 160 \\
Japan & 134 & 81 & 63 \\
Global Fund & 125 & & 87 \\
Sweden & 121 & & \\
Denmark & 119 & 80 & 66 \\
Norway & 105 & & 70 \\
IMF (Concessional & & 185 & \\
Trust Funds) & & 89 & 55 \\
Germany & & 86 & \\
Canada & & & \\
\hline
\end{tabular}

Source: OECD DAC, 2014a

Table 2 shows average 2010-12 data for ODA from major donors to Tanzania, Ghana and Uganda. Broadly, it can be seen that for all three countries the major donors are very similar in terms of both the range of countries/institutions and the rank-ordering. The USA tops the list for Tanzania and Uganda and is in second place for Ghana. ${ }^{4}$ Table 2 also shows the significance of the principal multilateral donors (the International Development Association [World Bank], the African Development Bank (AfDF), the European Union (EU), the Global Fund, ${ }^{5}$ and IMF Concessional Trust Funds) very clearly.

The OECD source which has been used as the principal basis for this section of the paper does not include data on the sectoral distribution of bilateral ODA disbursements before 2005, and does not give a sectoral distribution for multilateral aid. Ha-Joon Chang has recently criticised the extent to which the focus of the MDGs on poverty reduction and on the social sectors has tended to take attention, and resources, away from the more directly productive sectors of the economies of developing countries, thus handicapping the internal capacity for poverty reduction (Chang, 2014). Table 3 presents data for 2005 and 2002 for the sectoral distribution of bilateral ODA for Tanzania, Ghana and Uganda. 
Table 3 - Sectoral Distribution of Bilateral ODA Commitments - Tanzania, Ghana and Uganda (Percentages)

\begin{tabular}{|c|c|c|c|c|c|c|}
\hline & \multicolumn{2}{|c|}{ Tanzania } & \multicolumn{2}{|c|}{ Ghana } & \multicolumn{2}{|c|}{ Uganda } \\
\hline & 2005 & 2012 & 2005 & 2012 & 2005 & 2012 \\
\hline Bilateral ODA Commitments (Current US\$) & 1031.35 & 1314.83 & 846.15 & 1069.78 & 840.12 & 824.5 \\
\hline Social Infrastructure and Services & 40.38 & 61.38 & 12.77 & 45.11 & 53.75 & 56.75 \\
\hline Economic Infrastructure and Services & 18.19 & 8.39 & 6.02 & 22.03 & 3.17 & 12.36 \\
\hline Production Sectors & 2.39 & 11.00 & 5.57 & 18.75 & 4.49 & 18.19 \\
\hline Multisector & 3.73 & 6.65 & 2.38 & 4.18 & 2.43 & 4.27 \\
\hline Programme Assistance (including Food Aid) & 19.39 & 0.12 & 11.82 & 8.71 & 7.66 & 3.99 \\
\hline Action Relating to Debt & 9.22 & 0.00 & 56.89 & 0.00 & 11.28 & 0.00 \\
\hline Humanitarian Aid & 3.64 & 1.34 & 0.59 & 0.21 & 15.99 & 3.98 \\
\hline Unallocated/Unspecified & 3.06 & 0.91 & 3.96 & 1.01 & 1.23 & 0.46 \\
\hline
\end{tabular}

Source: OFCD DAC, 2014

Note: Data for 'action relating to debt' bias the results in this table for Ghana relative to Tanzania and Uganda. Bilateral debt relief peaked in 2007 for Tanzania and in 2005 to 2008 for Uganda. 
For all three countries included in Table 3 the preponderance of Social Infrastructure and Services (SIS) in the sectoral allocations of bilateral ODA is remarkable. For Tanzania there is an increase between 2005 and 2012 from about 40 percent to just over 60 percent. For Ghana the data is skewed by the impact of significant debt relief, but by 2012 SIS received about 45 percent of all bilateral ODA. For Uganda the proportion of bilateral ODA allocated to SIS amounted to about 55 percent in both 2005 and 2012. Economic Infrastructure and Services (EIS) allocations have significant variations over time and between countries for the two years shown in Table 3. For Tanzania in 2005 EIS received 18 percent of allocations, falling to about 8.5 percent in 2012. However, for Ghana and Uganda there were substantial increases in allocations to EIS, in the case of Ghana from 6 percent to 22 percent and in the case of Uganda from 3 percent to about 12.5 percent. Although the allocations to SIS were very much higher than those to EIS, Tanzanian experience in this respect runs counter to that of Ghana and Uganda, while all three countries fit the pattern identified by Chang for SIS.

Data for the Production Sectors in Table 3 show significant increases between 2005 and 2012 for all three countries: from about 2.5 to 11 percent of allocations in the case of Tanzania, from about 5.5 to nearly 19 percent in the case of Ghana, and from about 4.5 to just over 18 percent in the case of Uganda. Programme Assistance (including Food Aid) has only been substantial in the years covered by Table 3 in Tanzania, but all three countries show declines for this sector. Humanitarian Aid has only been at all substantial for Uganda, with all three countries, again, showing significant decreases.

In many respects the 'story' revealed by Table 3 is somewhat at variance from that unfolded by Chang, with sectors other than SIS receiving substantial allocations of bilateral ODA in 2005 and 2012 for these three countries. However, there can be no doubt about the overriding emphasis of bilateral ODA on SIS, with its focus on a form of 'poverty reducing' objectives which contrasts significantly with a poverty reduction strategy based on the generation of economic growth.

Table 4 - ODA in context

\begin{tabular}{lcccc}
\hline & \multicolumn{2}{c}{ ODA as \% of GNI } & \multicolumn{2}{c}{ ODA as \% of Govt Expenditure } \\
\hline & 1990 & 2011 & 2001 & 2012 \\
\hline Tanzania & 28.56 & 10.32 & $\begin{array}{c}78.59 \\
\text { (2004-5 Budget) }\end{array}$ & $\begin{array}{c}70.31 \\
\text { (2009-10 Actual) } \\
\text { Ghana }\end{array}$ \\
& 9.69 & 4.75 & 64.42 & 21.52 \\
& & & $(2001)$ & $(2012)$ \\
Uganda & 15.69 & 10.10 & 65.30 & 49.62 \\
& & & $(2001)$ & $(2012)$ \\
\hline
\end{tabular}

Sources: For all but Tanzanian ODA as \% of Govt Expenditure - World Bank, 2014a. For Tanzanian ODA as \% of Govt Expenditure - URT, 2005b: Table 8.1 and URT. 2010a: Table 7.2. Note that Government Expenditure includes both Recurrent and Investment Expenditure. 
Table 4 sets ODA into a wider economic focus for all three countries included in this review, with two specific dimensions - ODA receipts as a percentage of Gross National Income (GNI) and ODA as a percentage of Government Expenditure. ${ }^{6}$

For the first dimension, it can be seen that in 1990 ODA was only just below 30 percent of Tanzanian GNI (an exceptionally high ratio and indicative of Tanzania's low level of income), but by 2011 this had fallen to just over 10 percent, mainly reflecting strong economic growth (see below) in the intervening two decades (rather than reflecting a significant reduction in ODA). For Ghana, ODA as a proportion of GNI approximately halved over the same period, falling from about 10 percent to about 5 percent. For Uganda, there was a 50 percent fall in this ratio, reflecting both strong economic growth and a sustained high level of ODA. Even at 10 percent of GNI the level of ODA to Tanzania and Uganda in 2011 can be regarded as considerable.

For the second dimension, it can be seen that in 2004-5 ODA as a percentage of government expenditure was around 80 percent in Tanzania, falling to around 70 percent by 2012 reflecting the fact that total government expenditure includes both non-recurrent ('development' and capital investment) expenditure, encompassing many activities supported by ODA), and recurrent expenditure (regular government activity). For Ghana ODA as a percentage of government expenditure fell from 64 percent in 2001 to 21.5 percent in 2012, while for Uganda the equivalent figures were 65 percent in 2001 and 50 percent in 2012. In this respect the Ghanaian data suggests something of a drawing back of the significance of ODA through the 2010s by comparison with Tanzania and Uganda, but for all three countries ODA has had a very considerable role in funding government expenditure.

Figure 1 gives a clear indication of the relative significance of different types of Tanzanian government financial sources. Budget support provided about half of 'foreign revenues' for the period reviewed in the joint Irish Aid/DFID evaluation. Foreign revenues provided about 42 per cent of the sum of foreign and tax revenues for both periods included in the figure, and about 40 per cent of the sum of foreign and domestic revenues for both periods. This confirms the very significant position of foreign financial inflows in the funding of Tanzanian government expenditure. 
Figure 1 - Tanzania: Five year comparison of revenues by type (as a proportion of GDP)

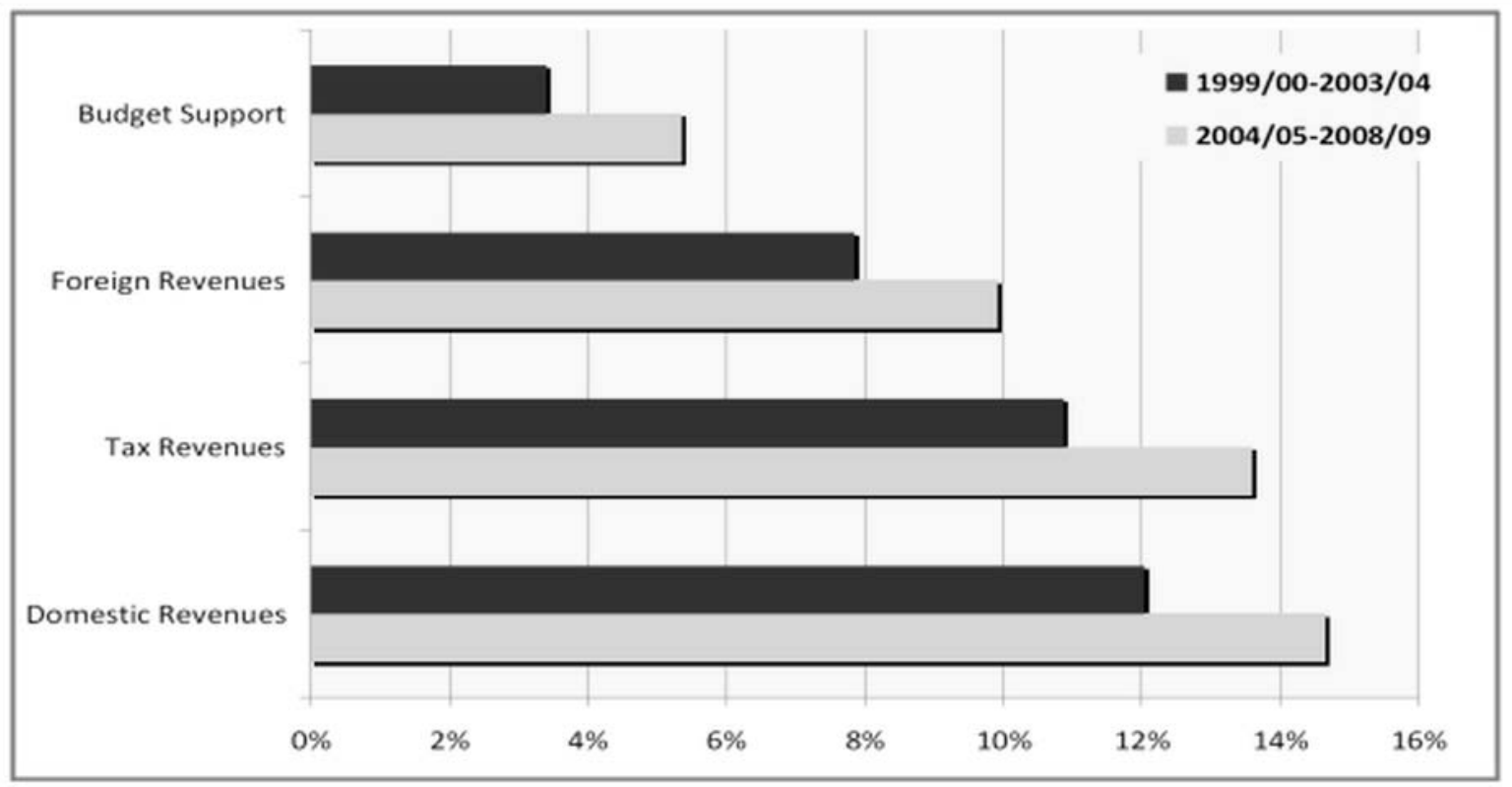

Source: Irish Aid/DFID, 2010: 21.

Note: The sources for the data in this table were World Bank and IMF documents as specified in the Irish Aid/DFID report.

Table 5 - Net Effect of International Financial Flows: Tanzania, Ghana and Uganda for about 2012 (US\$ millions)

\begin{tabular}{|c|c|c|c|}
\hline & Tanzania & Ghana & Uganda \\
\hline Net ODA Inflows & 2,436 & 1,800 & 1,582 \\
\hline ‘NGO’ Inflows & 39.6 & 29.8 & 54.5 \\
\hline $\begin{array}{l}\text { 'Umbrella organisation' } \\
\text { inflows }\end{array}$ & 158.5 & 97.8 & 165.3 \\
\hline $\begin{array}{l}\text { Personal Remittances } \\
\text { (inflows) }\end{array}$ & 59 & 121 & 642 \\
\hline $\begin{array}{l}\text { Foreign Direct Investment } \\
\text { (net inflows) }\end{array}$ & 1,706 & 3,294 & 1,721 \\
\hline Net Financial Inflows & 4,399.1 & $5,342.6$ & $4,164.8$ \\
\hline $\begin{array}{l}\text { Imports - Exports (Goods } \\
\text { \& Services) }\end{array}$ & $-4,140$ & $-5,196$ & $-2,895$ \\
\hline
\end{tabular}

Sources: Row 1 - Table 1 above; Row 2 -d-portal.org, 2014; Rows 3, 4 and 6 - World Bank, 2014a.

Note: 'NGO' inflows relate to 'traditional' NGOs - excluding 'umbrella organisation' aid - see Table 7 below.

Table 5 sets out the main elements of international financial flows for the three countries in order to put ODA into another form of 'context'. ${ }^{7}$ One interesting aspect of the data in this table is that for Tanzania and Ghana the net effect of ODA, NGO aid, 'umbrella organisation' aid, personal remittances and foreign direct investment on the balance of international payments is approximately neutral. Only in the case of Uganda is there a substantially positive net impact from these five flow series. The net ODA inflows have already been 
presented in Table 1 . The international NGO inflows were surprisingly difficult to locate, ${ }^{8}$ but it can be seen that the overall financial impact is very small when compared with ODA (1.6 percent for Tanzania and Ghana, and 3.4 percent for Uganda). This is not to belittle the importance of the role of international NGO contributions to the three countries, part of which is now related to acting as an instrument for the implementation of some types of ODA which - it is judged - can be more effective if handled by NGOs.

\section{Box 1 - The Action Aid definition of 'phantom aid'}

Our definition of phantom aid includes aid that is:

- not targeted for poverty reduction, estimated to be worth US\$4.9 billion

- double counted as debt relief, totalling US\$9.4 billion

- overpriced and ineffective Technical Assistance, estimated at US\$13.8 billion

- tied to goods and services from the donor country, estimated at US\$2.7 billion

- poorly coordinated and with high transaction costs, estimated at US\$9 billion

- too unpredictable to be useful to the recipient - lack of data prevents an estimate

- $\quad$ spent on immigration-related costs in the donor country; totalling US\$1.5 billion

- spent on excess administration costs; totalling US\$0.4 billion

In total, at least $61 \%$ of all donor assistance is phantom aid, with real aid in 2003 accounting for just US\$27 billion, or only $0.1 \%$ of combined donor income.

Source: Action Aid, 2005: 17.

Another aspect of the comparison between ODA and NGO aid is the extent to which the level of ODA is overstated due to the inclusion of funds ('phantom aid') which should not be regarded as contributing significantly to the development of recipient countries. The main source for the estimation of the extent of 'phantom aid' is a critical report by Action Aid (2005). Box 1 below presents the Action Aid definition of 'phantom aid'. This is a very controversial issue, and a measured and sympathetic response from Richard Carey (2005) ${ }^{9}$ pinpoints the main weaknesses of this radical approach. Although the 'broad brush' used in the definition and estimation of 'phantom aid' can be seriously challenged there is sufficient of a 'grain of truth' in the approach which makes it of interest to serious discourse. Another shortcoming of the 'phantom aid' phenomenon is that the data in the Action Aid report was broken down by donor rather than by recipient country, making it less relevant to the discussion in this paper. The most recent report in the 'Real Aid' series produced by Action Aid does not mention 'phantom aid' (Action Aid, 2011).

In recent years ODA donors have been concerned to make inter-country ODA allocation more systematic, reflecting international development objectives. Such concerns could have significantly affected the amount of ODA received by the three countries on which this paper is focussed. In 2010-11 the UK's DFID undertook Bilateral and Multilateral Aid Reviews (DFID, 2011a; 2011b; and DFID, 2011c). The Bilateral Aid Review aimed to cut the number of countries to which the UK contributed ODA from around 87 to around 27 countries. A 
central part of the allocation process was the application of a "Needs and Effectiveness Index" - "Needs" being based largely on poverty reduction criteria and "Effectiveness" being based on governance criteria (refer to Tribe, 2013). Following this review all three countries remained within the 27 'survivors' as "DFID priority" countries. The projections of DFID ODA allocations are shown in Table 6 . It can be seen that all three countries were to experience slight falls in the proportion of UK Aid allocated to them. However, in money terms Uganda was scheduled to have a slight increase and then a slight fall in actual ODA allocations over the period 2010-11 to 2014-15, while Tanzania and Ghana were scheduled to have a slight increase in UK ODA allocations (DFID, 2011b: Annex F).

Table 6 -UK Aid to Tanzania, Ghana and Uganda before and after the 2011 Bilateral Aid Review

\begin{tabular}{lccc}
\hline & Tanzania & Ghana & Uganda \\
\hline $2010-11 \%$ UK Aid & 5.17 & 2.93 & 3.10 \\
$2010-11$ UK Aid fm & 150 & 85 & 90 \\
$2014-15 \%$ UK Aid & 4.08 & 2.43 & 2.18 \\
$2010-11$ UK Aid fm & 168 & 100 & 90 \\
\hline
\end{tabular}

Source: DFID, 2011a; 2011b.

During the period 2010-11 to 2014-2015 UK ODA was scheduled to increase from $0.57 \%$ to $0.70 \%$ of Gross National Income (House of Commons, 2013a: 14). The Technical Report relating to the DFID Bilateral Aid Review gives the basis for the changes to ODA allocations between countries (DFID, 2011b). The DFID Multilateral Aid Review (DFID, 2011c) examined the 'alignment' between the priorities of multilateral bodies to which UK ODA had been allocated, their performance, and the priorities of DFID - this review has itself recently been subjected to close scrutiny by the International Development Committee of the House of Commons (House of Commons, 2013b).

Table 7 - Umbrella Organisation Aid to Tanzania, Ghana and Uganda, 2012 US\$

\begin{tabular}{lccc}
\hline Organisation & Tanzania & Ghana & Uganda \\
\hline GAVI & $30,761,553$ & $44,831,988$ & $12,527,115$ \\
Global Fund & $120,419,497$ & $63,941,515$ & $148,522,014$ \\
HIROs & $3,938,872$ &.. & $4,265,490$ \\
\hline Total & $158,519,922$ & $97,773,493$ & $165,314,619$ \\
\hline
\end{tabular}

Source: d-portal.org, 2014.

Another development on the 'aid front' has been a significant increase in the financial flows associated with what have been termed here 'umbrella organisations'. Bodies such as GAVI, the Global Fund and HIROs, ${ }^{10}$ included in Table 7, receive funding from a range of organisations, including bilateral and multilateral ODA donors, international NGOs (both conventional and 'new' such as Comic Relief), private charities (such as the Bill and Melinda Gates Foundation) and the corporate sector (e.g. Vodaphone) and commit their aid contributions to specific objectives relating to medical campaigns. The three organisations identified in Table 7 have accounted for around 5 to 10 percent of the value of ODA receipts for Tanzania, Ghana and Uganda in recent years. Although the international collaboration which is reflected in Table 7 relates particularly to the medical/health sector, more generically this type of multi-agency funding model has become more common across the 
'aid' spectrum and has recently been referred to as 'blending' (Africa Progress Panel, 2014: Chapter 4). The range of organisations involved in 'blending', and identified by the Africa Progress Panel (chaired by Kofi Annan), also includes the Eurobond market and other forms of finance which are not included in ODA but are included in ODF. ${ }^{11} \mathrm{~A}$ higher proportion of international development investment, project financing and management, and sector development now involves collaboration and co-financing between these groups - privatepublic partnerships are one example.

\section{3 - Aid, Economic Growth and Poverty Reduction}

Although the objectives of international aid are much wider than simply to contribute to economic growth, economists' judgement about aid effectiveness have mainly focussed on analysis of the relationship between ODA and economic growth (Griffin, 1970; Mosley, 1980; Easterly, 2003; 2006; Easterly et al., 2004; Gomanee et al., 2005; McGillivray et al., 2006; Rajan and Subramanian, 2008; Clemens et al., 2012; Arndt et al., 2015; Lof et al., 2015). Over the forty years covered by these references the focus of research has, inevitably, changed - however, the basic methodology has remained stable, being based on cross-country quantitative analysis using multiple regression techniques. There do not appear to have been any parallel, high profile, single country or grouped countries case studies. In addition, there have been few economic studies which aspire to trace the relationship between ODA and economic growth based on growth theory, and particularly on modern, or endogenous, growth theory. ${ }^{12}$ The most recent cross-country studies on the ODA-economic growth relationship have been particularly careful to distinguish between ODA which is focused on contributing to economic growth within a relatively short time horizon, and ODA which is either not focused on economic growth per se (e.g. humanitarian and/or disaster aid) or which is directly focussed on poverty reduction and which does not therefore have an economic growth objective. In addition this more recent economic analysis allows for a time-lag between ODA receipts and impacts (Clemens et al., 2012; Arndt et al., 2015; Lof et al., 2015). The results from these recent studies conclude that ODA has a relatively modest, but significant, positive role in contributing to economic growth in recipient developing countries - while earlier studies based on less complex interpretations of the statistics came to considerably more negative conclusions.

In the context of systematic analysis of the impact of ODA one of the most important analytical issues is to compare the outcomes based on actual ODA receipts (i.e. ODA disbursements and programme implementation rather than simply ODA commitments) by developing countries with the 'counterfactual' (what would be likely to have occurred in the absence of ODA receipts). While such analysis based on comparison of actual with counterfactual outcomes is notably rare, the counterfactual approach is the fundamentally correct methodology. 
Table 8 - GDP Growth for Tanzania, Ghana and Uganda 1990 to 2012

\begin{tabular}{lcccc}
\hline GDP 1990 & $\begin{array}{c}\text { GDP 2012 } \\
\text { constant 2005 } \\
\text { US\$ million }\end{array}$ & $\begin{array}{c}\text { Annual average } \\
\text { constant 2005 } \\
\text { US\$ million } \\
\text { GDP growth } \\
1990-2012\end{array}$ & $\begin{array}{c}\text { 2012 GDP as a \% } \\
\text { of 1990 GDP }\end{array}$ \\
\hline Tanzania & $7,454.02$ & $22,431.97$ & 5.24 & 334 \\
Ghana & $5,509.02$ & $18,374.19$ & 5.55 & 362 \\
Uganda & $3,465.58$ & $14,734.66$ & 6.81 & 481 \\
\hline
\end{tabular}

Source: World Bank, 2014a and author's calculations

Some recently published empirical work on African economic growth is very instructive on the ODA-economic growth relationship. Rodrik opens his 2014 National Bureau of Economic Research paper in these terms:

"It is clear that Africa has benefited from a particularly favorable external environment during the last two decades. Global commodity prices have been high and interest rates low. Private capital flows have supplemented increased official assistance. China's rapid growth has fueled demand for the region's natural resources and has stimulated direct investment in African economies. The global financial crisis, meanwhile, had little direct impact, given African countries' weak financial links with the rest of the world and low levels of financialization." (Rodrik, 2014: 1-2).

In the body of his paper Rodrik emphasises the significance of Economic Reform, of institutional quality and of reduced civil conflict as factors explaining the better African economic performance during the period covered by Table 8 . The first two of these favourable factors have been associated with ODA programmes (and what might be regarded as 'leverage' by the IFIs and the donor community) but would not necessarily show up in some of the regression analysis focused on the ODA-economic growth relationship. In their recent joint article on African economic development McMillan, Rodrik and Verduzco (2014) focus particularly on structural change and productivity growth and emphasise the importance of economic reform and 'improved' governance in contributing to accelerated African economic growth. A tantalising question therefore relates to the distinction between African economic growth which would have occurred with significantly less ODA, and that part of economic growth which has resulted from the ODA inflows. Given the higher and sustained levels of ODA to Tanzania, Ghana and Uganda, the countries focussed on in this paper, it would be difficult to conclude that ODA has not been a major factor in the improved economic performance.

Apart from the relationship between ODA inflows and economic growth there has been considerable attention given to the contribution made by ODA to poverty reduction in recipient countries. The role of ODA (and of the 'donor community') in reducing the extent of poverty in developing countries was given additional emphasis during James Wolfensohn's tenure as the President Director of the World Bank, and featured the introduction of Poverty Reduction Strategy Papers (World Bank, 2014b) as mandatory instruments of development planning, together with the PRSP Sourcebook (World Bank, 2002). ${ }^{13}$ 
Table 9 - Poverty Headcount (\%) < US\$1.25 PPP per day

\begin{tabular}{llll}
\hline & Tanzania & Ghana & Uganda \\
\hline 1992 & 72.59 & 51.07 & 70.01 \\
Most recent & $67.87(2007)$ & $28.59(2006)$ & $38.01(2009)$ \\
\hline
\end{tabular}

Source: World Bank, 2014a

The issue for this paper is to consider to what extent ODA has contributed to poverty reduction in Tanzania, Ghana and Uganda. Table 9 shows poverty headcount data for the three countries, comparing data for 1992 with the most recent comparable data from World Development Indicators (World Bank, 2014a). The poverty headcount is, of course, the number (or proportion) of the population with an income below the specified level US\$1.25 currently being the international poverty line below which people are deemed to be in "extreme poverty". In the case of Tanzania the World Bank data shows that in 1992 slightly more than 70 percent of the population were in extreme poverty, with the proportion falling to just under 70 percent in 2007. For Ghana the comparable proportion had fallen from 51 percent in 1992 to just under 30 percent in 2006, while for Uganda the comparable data were 70 percent in 1992 and 38 per cent in 2009. This poverty indicator is open to a number of caveats, not only concerning the validity of the US\$1.25 per day (in 2005 PPP\$) poverty line, but also because the data is based on periodic household surveys undertaken with World Bank support with data being generated for different years in different countries. However, this is the best that we have. The implication of the data in Table 9 is that the extent of extreme poverty has 'flat-lined' in Tanzania over the last 20 years, while there has been significant success in reducing the extent of extreme poverty in both Ghana and Uganda. This 'flat-lining' was remarked upon in the recent major evaluation study prepared for Irish Aid and the UK DFID (Irish Aid/DFID, 2010).

The poverty line is rather a 'blunt instrument' since it relates to an economic or 'incomerelated' definition of poverty (with all of the associated limitations), and also gives little indication of the shape of the frequency distribution lying below the poverty line - i.e. it does not tell us anything about the depth of poverty below the poverty line. Table 10 contains data relating to two multidimensional poverty indices which have been included in the UNDP's Human development Reports over the last twenty-five years.

For the Human Poverty Index there is data for 1998 and 2009 values, with a higher index value indicating a greater degree of multidimensional poverty. The data for Tanzania confirm the 'flat-lining' of poverty reduction suggested by the poverty-line based data in Table 9, while the data for Ghana and Uganda confirm the marked reduction in poverty shown by their poverty line data. While the poverty line data is essentially a measure of income poverty, the Human Poverty Index data included equal weighting of three measures relating i) the percentage of people not expected to survive to age 40 , ii) the percentage of adults who are illiterate, and iii) a combined measure based on a) the percentage of people without access to safe water, b) the percentage of people without access to health services, and c) the percentage of moderately and severely underweight children under five years of age (from UNDP, 1998: 110 - see UNDP, 2015). 
Table 10 - Human Poverty Index and Multidimensional Poverty Index

\begin{tabular}{lccc}
\hline & Tanzania & Ghana & Uganda \\
\hline HPI - 1 1998 & 29.2 & 35.4 & 39.7 \\
HPI - 1 2009 HDR & 30.0 & 28.1 & 28.8 \\
MPI 2006-2008 & n. a. & $0.186(2008)$ & $0.399(2006)$ \\
Population in MPI & n. a. & 39.2 & $74.5(2006)$ \\
2006-2008 & $0.335(2010)$ & $0.144(2011)$ & $0.359(2011)$ \\
MPI 2010-2011 & $66.4(2010)$ & $30.5(2011)$ & $70.3(2011)$ \\
Population in MPI & & &
\end{tabular}

Sources: HPI - 1 for 1998 UNDP HDR 2000 Table 4; HPI - 1 for 2009 UNDP HDR 2009 Table I; MPI UNDP HDR 2014 Table 6

Note: Values for the Human Poverty Index were published by the UNDP for about 10 years starting with 1997 and the final round of published data is for the most recent year's data available at the time of the preparation of the Human Development Report 2009. There appears to have been no attempt to provide any reconciliation or overlap between the HPI and MPI series, making comparisons over longer periods of time very difficult or impossible. Note that all UNDP Human Development Reports are available from UNDP (2015).

By comparison the data in Table 10 for the Multidimensional Poverty Index (MPI), which replaced the Human Poverty Index in 2010, also shows higher degrees of poverty the higher the index value, but has an 'MPI Poverty Line' indicating the proportion of the population living in multidimensional poverty. The data for the MPI were incomplete for Tanzania at the time of writing, but with this measure Ghana clearly has a degree of poverty lower than that for Tanzania and Uganda in this period, and for Ghana and Uganda the period between the middle and the late 2000s shows a drop in the extent of poverty, which is consistent with other measures.

Table 11 - Human Development Index - 1990 and 2012

\begin{tabular}{lccc}
\hline & Tanzania & Ghana & Uganda \\
\hline 1990 & 0.353 & 0.427 & 0.306 \\
HDI Rank 2001 & 140 & 119 & 141 \\
2012 & 0.476 & 0.558 & 0.456 \\
HDI Rank 2012 & 152 & 135 & 161 \\
\hline
\end{tabular}

Source: UNDP, 2014 for 2012 data; UNDP, 2001 for 2001 data - see UNDP, 2015

Table 11 shows data for the Human Development Index (HDI), generated by the United Nations Development Programme, for 1990, 2001 and 2012. ${ }^{14}$ The HDI, which was the original composite 'development index' produced by the UNDP, shows a significant increase over the period 1990 to 2012, indicating an advance in the standard of living for all three countries. In general we would expect that an increase in the HDI would be associated with a reduction in the level of absolute poverty. Unfortunately the global HDI ranking for 1990 is extremely difficult to access, and the ranking for 2001 is the oldest which is readily available. The global ranking figures for 2001 and 2012 reflect an increase in the number of countries 
included in the ranking, but the data in Table 11 also suggest that Tanzania, Ghana and Uganda have slipped down the international HDI league table over these years.

A 'soft' conclusion to the issue of the contribution of ODA to poverty reduction (and to improvements in the standard of living) is possible, as with the contribution of ODA to economic growth. Not only has strong economic growth over a period of 30 years had an opportunity to impact on poverty and the standard of living in all three countries (with the weakest poverty reduction impact being for Tanzania) but there can be only a limited empirical connection between ODA and economic growth given the likelihood that economic growth has resulted significantly from economic reform and improved economic governance.

\section{4 - Tanzanian Aid Issues}

Sections 4 and 5 can be viewed in the context of recent literature focussed on significant changes in 'aid architecture' - the structures and procedures within which ODA operates. In particular the contributions of Severino and Ray (2009; 2010) and Severino (2011), based on experience at the highest level in the OECD DAC (Development Assistance Committee), have been very influential in suggesting changes in the ODA 'mindset'. Kaberuka (2011), also from within the OECD DAC 'stable', outlines some shortcomings and opportunities relating to ODA in sub-Saharan Africa. Kharas (2007) provides an overview of long-term ODA trends to the middle of the first decade of the $21^{\text {st }}$ century, while Hyden (2003) reflects on his East African experience in proposing changes to aid donor strategies.

Section 4 aims initially to review some of the main controversial issues relating to ODA and affecting Tanzania in recent years - the issues selected are Budget Support (BS), corruption, and alignment with the principles of the Paris Declaration. In addition there is brief consideration of the literature on the impact of ODA on Tanzanian development, and of recent Tanzanian policy relating to the management of ODA. However, before dealing with the selected issues two other points are discussed briefly.

In the joint Irish Aid/DFID evaluation report covering the period 2005-2010 (Irish Aid/DFID, 2010) there are frequent mentions of the views of the "DPs", signifying "Development Partners". "DPs" is part of the 'new language' of ODA - reference to 'donors' and 'recipients' being regarded as politically incorrect. Previously the literature tended to refer to 'recipients' and to 'donors' or 'the donor community'. If both 'recipients' and 'donors' are development partners, then it would be necessary to find alternative words the distinguish between the two groups. The joint report's references to "DPs" refer to members of the 'donor community', while the Tanzanian 'Development Partners Group' includes both the donors community as well as the Government of Tanzania (URT, 2005a). The 'donor community' perspective of the joint report is understandable, not least because the report was commissioned by and undertaken on behalf of Irish Aid and the DFID. The 'recipient' position is probably given more consideration in the joint report than might have occurred previously, but it does appear that the 'new focus' of the ODA relationship on 'recipients' rather than 'donors', embodied in the Paris Declaration and successor international agreements, has not been fully incorporated. 
In recent years the significance of environmental issues in the context of ODA has come to assume a more important role in the policies and allocations of the donor community. In a recent working paper Kahyarara (2014) explains that "focusing on the funding for environmental degradation projects, the study notes that budget expenditure allocation to these activities is around 0.04 per cent of Tanzania's total expenditure. This is a problem given that in the near future financing for climate change alone would need around US\$1 billion per year (or nearly 10 per cent of the budget). Ultimately, aid money is critical for Tanzania, as over 90 per cent of funds for environment come from donors." Kahyarara's working paper provides a comprehensive overview of environmental policy in Tanzania, including the role of ODA.

\section{$4 a-$ Budget support}

Chapter 3 of the joint Irish Aid/DFID evaluation report (Irish Aid/DFID, 2010) examines budget support (BS) and public financial management in some considerable detail. The December 2014 version of the DFID Operational Plan for Tanzania 2011-2016 (DFID, 2014: 7) states that "DFID Tanzania will reduce and eventually cease to use General Budget Support (GBS) during the period covered by this plan, as the 2010 independent Country Programme Evaluation suggested that GBS was not the most effective way to deliver results in the current circumstances." This decision by DFID, purportedly based on the joint evaluation report, appears to be driven more by internal UK factors than by the findings of the evaluation report, and the wording of the 2014 DFID document gives a misleading representation of the evaluation's recommendations. To quote the evaluation: "BS has been successful in providing increased discretionary funds to high priority areas. It has not generated improved democratic accountability and has had limited impact as an instrument of policy leverage. There remains a continuing and important place for GBS in Tanzania, where substantial improvement in the coverage of public services is necessary to progress towards the MDGs. However, the evaluation supports a relative reduction in the scale of GBS and SBS until the issues of quality, efficiency and equity in public spending are addressed through a revitalised dialogue process" (Irish Aid/DFID, 2010: 68 para 6.10). The internal UK factors are principally the National Audit Office's recommendation to use BS cautiously (NAO, 2008), the similar recommendation made by the Independent Commission for Aid Impact (ICAI, 2012 - see below), and pressure on the Conservative/Liberal Democrat Coalition Government from Conservative backbenchers to reduce or eliminate the use of Budget Support in the UK Aid programme. Of these the third has perhaps been the most influential on UK government decisions about BS. The antagonism of backbench Conservative MPs, and of the UKIP political party, to ODA commitments is highlighted in a Financial Times report (FT, 2014) and in a report in the Daily Mail (Daily Mail, 2014). The NAO and ICAI reports, in which Tanzania features somewhat positively, show some improvement in achieving BS objectives over the period from around 2005 to 2010. The joint Irish/DFID evaluation actually found that some of the difficulties experienced with DFID's use of Budget Support in Tanzania had been due to poor communication between DFID personnel in London and in Dar es Salaam, with "HQ appreciation of how the application of BS and Paris Principles changed and developed over time was insufficient for them to give advice and support. More mutual lesson learning round the realities of programme management would benefit both sides" (Irish Aid/DFID, 2010: 64 para 5.38). 
In 2010 the UK government established a new independent evaluation body called the Independent Commission for Aid Impact (ICAI) and one of its early reports focussed on DFID BS (ICAI, 2012). This report summarises an international consensus on BS which had been developed during the negotiations (in which DFID had taken a leading role) leading to the launch of the Paris Declaration in 2005 and this consensus is reproduced in Figure 2.

Figure 2 - The 'Paris Consensus' on budget support and aid effectiveness

Traditional projects

- Donor-led

- Undermines ownership and accountability

- Fragmented assistance

- Bypasses country systems

- Supports capital expenditure and technical assistance

- Donor support is more volatile

- Higher aid-management costs

- Sustainability more difficult to achieve

\section{Budget support}

- Partner country-led

- Strengthens national ownership and accountability

- Facilitates donor harmonisation

- Uses and strengthens country systems, including the national budget

- Supports recurrent expenditure

- Donor support is more predictable

- Lowers aid-management costs

- Generates more sustainable results

Source: ICAI, 2012: 4.

Tripp's UNU WIDER working paper (2012: 17) has a telling discussion of BS, the conclusion of which is as follows: "Many donors in Tanzania suspect that a large chunk of the funds that disappear are lost through the GBS or through the basket-funding process. This is because, as Barkan (2009) cogently explains, GBS represents large amounts of funds in unaudited accounts or accounts for which audits are not available to the public. This allows a large portion of the budget to support corruption and to be used as political finance." This notwithstanding, the laudable objectives which led to the introduction of BS as an ODA 'modality' within the Paris Declaration framework (as summarised in the ICAI's report and in Figure 2 above) are clearly articulated in Tripp's paper. One dimension of this paper is the extent to which it depends, through a substantial set of interviews, on 'perceptions' and 'opinions' of the link between corruption and BS rather than hard facts.

$4 b-$ Corruption

Much of the literature relating to the Tanzanian ODA experience mentions corruption as a major issue, and this has been one factor accounting for a degree of 'aid volatility' (see for example Guardian, 2014 and DFID, 2014). The joint Irish Aid/DFID evaluation study devotes 
a significant amount of space to the issue of corruption (2010: Chapter 2) but concludes that Tanzania's corruption profile is little better or worse than that of other countries in the region. The evaluation report is peppered with references to corruption and it concluded that further research and analysis was needed as the basis for the development of more robust anti-corruption measures.

The well-respected Helleiner Report of 1995 (Helleiner et al., 1995; Wangwe, S. M., 2002) is cited in the joint Irish Aid/DFID evaluation report in the context of corruption:

"The Helleiner Report acknowledged these problems and was strongly critical of GoT. However, it also considered the ways in which DP [i.e. donor community] behaviour had contributed to this situation, by undermining ownership, by lacking transparency and predictability and by pursuing aid modalities which burdened the limited administrative capacities of GoT. The report was well received and created a positive environment for reforms, culminating in the Tanzania assistance strategy, PRBS (Poverty Reduction Budget Support] and, later, the joint assistance strategy for Tanzania (JAST)" (Irish Aid/DFID, 2010: 30).

The Tanzanian assistance strategy will be discussed in more detail in section 5 of this paper.

In a paper produced in 2007 Rotberg provides a 'development overview' of seven subSaharan African countries (one of which was Tanzania - another two being Ghana and Uganda), including the issue of corruption. A major shortcoming of this source is the lack of citations (i.e. direct attribution of sources), but this is always likely to be a problem in research on corruption. However, Rotberg (2007) gives an overview of corruption which comes from a respected academic institution (i.e. within the John F. Kennedy School of Government in Harvard University). He cites Transparency International data showing Tanzania as 93rd out of 163 countries in 2006 on the Corruption Perceptions Index, and the Global Integrity Index for 2006 which gave Tanzania an overall score of 59 (which is described as 'very weak'). The other evidence of significant corruption assembled by Rotberg is significant. In the international sphere the Tanzanian purchase of an air traffic control system from the UK (see also BBC, 2001; Guardian, 2006) developed into a longrunning saga involving alleged corruption on the part of British Aerospace - this case has been a cause célèbre. In the domestic sphere Rotberg cites a wide range of cases in substantiating his arguments.

The corruption phenomenon in Tanzania is highlighted in the UNU WIDER working paper by Tripp (2012) which was cited earlier. While the main statistics presented in this paper are sourced from Transparency International there is also a wide range of other primary and secondary evidence about corruption in Tanzania and its relationship to ODA. Tripp cites the World Bank CPIA measure in her discussion, implying a significant deterioration in 'country performance' ranking (i.e. weakening of the governance standards), and suggests that "some in the Bank feel the ranking should be lower but that would put it out of sync with countries that are regarded less favourably than Tanzania" (Tripp, 2012: 13). This is consistent with the joint Irish Aid/DFID evaluation of 2010 in finding that, despite its poor record on corruption, Tanzania is no worse - and probably better - than other ODA recipients in this respect. Tripp's paper presents data for "Donor support of political reform, 
2000-10" demonstrating the extent to which ODA has had the governance and reform process as a key target of its funding (Tripp, 2012: Table 1).

The World Bank's relationship with the current Tanzanian Joint Assistance Strategy is set out in a document which is now publicly available. This document refers explicitly to the corruption issue in these terms: "Corruption and accountability emerged as important themes during the 2010 election campaign. The president made strong commitments on both issues in his inaugural address. Seven high-level corruption cases involving an estimated US\$1 billion took place between 2000 and 2008, tainting Tanzania's reputation. The government took decisive actions that helped restore confidence, but definite solution of some of the cases remains a matter of concern. Renewed government commitment on these issues would help address the perception of increasing corruption" (World Bank, 2011: 1-2). With the World Bank being the lead member of the donor community these views clearly carry some considerable weight on the issue of corruption.

The suspension of UK and other countries' ODA provided on a BS basis in October 2014 (Guardian, 2014) appears to have been prompted by investigations of the Tanzanian Parliament's Public Accounts Committee into allegations of widespread corruption. The report in the Guardian newspaper (Guardian, 2014) emphasises the central role of Tanzanian opposition politicians in pressing for suspension of ODA, rather than the roles of the UK political system or of international evaluation reports.

The corruption issue is clearly significant, but has tended to be clouded by limitations of both a conceptual and empirical nature. First, the focus on international comparative indices of corruption (such as Transparency International's Corruption Perception Index - TI, 2015 ) tends to cover only private sector views of public sector corruption, implying that the 'blame' lies with the public sector rather than with the private sector. This echoes the World Bank definition of corruption: "the abuse of public office for private gain" (World Bank, 2015). A more balanced view would be critical of both the public and the private sectors. Indeed, from both an ethical and developmental viewpoint corruption entirely within the private sector is just as much of an issue as that covered by the World Bank definition. Second, the case of the air traffic control system which was cited above involved alleged corruption essentially initiated from a private sector international source. This is an issue which has long history, and for which new UK legislation was approved in 2010 covering all forms of bribery and corruption with, inter alia, the objective of getting better control over the activity of donor country private sector institutions (Guardian, 2010; Ministry of Justice, 2011). Bribery and corruption is an international issue on which the OECD, for example, has a continuing focus (OECD, 2014). Third, a distinction has to be made between 'international' corruption influencing broad ODA allocations between countries, programmes and contractors on the one hand, and 'domestic' corruption which affects the extent to which the intended beneficiaries of ODA programmes actually receive support, with resources being misappropriated, on the other hand. This 'domestic' dimension was the main focus of a UK report by the Independent Commission on Aid Impact which was critical of DFID's record on anti-corruption measures relating to poverty reduction programmes (ICAI, 2014). 
4c-Alignment with the Paris Declaration

Box 2 - The Principles of the Paris Declaration

1. Ownership: Developing countries set their own strategies for poverty reduction, improve their institutions and tackle corruption.

2. Alignment: Donor countries align behind these objectives and use local systems.

3. Harmonisation: Donor countries coordinate, simplify procedures and share information to avoid duplication.

4. Results: Developing countries and donors shift focus to development results and results get measured.

5. Mutual accountability: Donors and partners are accountable for development results.

Source: OECD DAC, 2005 and 2008

The central principles of the Paris Declaration of 2005 are shown in Box 2: with these principles applying to all donors and recipients within the ODA system. There have been two main strands tracking the implementation of the new aid architecture represented by the Paris Declaration (OECD DAC, 2005 and 2008). The first of these has been through a series of international meetings in Rome (2003), Paris (2005), Accra (2008), Busan (2011) and Mexico City (2014) (OECD DAC, 2015a). At the Busan meeting the Global Partnership for Effective Development Cooperation was established, as a system monitoring the process of securing alignment with the principles of the Paris Declaration - by ODA donors and by recipients (Global Partnership, 2013). The second strand is represented by the major multi-country evaluation study undertaken by IOD PARC, funded by the OECD DAC Paris Declaration Secretariat and by the Danish Institute for International Studies (Wood et al., 2011; Betts and Wood, 2013; Wood and Betts, 2013). This evaluation study covered 7 donor institutions and 21 recipient countries. As well as the overall synthesis report, and the final report, individual components of the evaluation are available for downloading from the OECD evaluation network website (OECD, 2015b). Tanzania was not one of the countries selected for detailed study, but the ten African countries which were studied included Ghana and Uganda (which have been used as comparators in the first two main sections of this paper).

Perhaps the overall conclusion to be reached from the Final Report of Phase 2 of this major evaluation (Wood et al., 2011) is that, although progress had been made towards implementing the principles of the Paris Declaration between 2005 and 2010, the implementation process was relatively slow and uneven, varying significantly between individual principles and individual countries. This relatively slow progress is not a surprise given the political and administrative complexity of the implementation. Also unsurprisingly, the fact that the evaluation found that there were significant shortcomings among both the recipient countries and the donor institutions still needs to be registered by the 'aid industry'. In particular, the tendency for donor evaluations to 'blame' recipient countries for slow progress while overlooking the slow progress of donor institutions (vide Irish Aid/DFID, 2010: vi-xv) and for recipient country evaluations to 'blame' donor institutions for slow progress (URT, 2009), is rather unhelpful. One clear impression is the extent to which the international system which generated the Paris Declaration significantly underestimated the 
complexity, and time scale, of the prospective implementation of the principles embodied in the declaration.

An early (i.e. pre-Paris Declaration) review of Norwegian ODA to Tanzania gives an interesting insight into the principles and practice of a leading 'Nordic' donor, with a particular focus on 'conditionality' (Selbervik, 1999). The Norwegian approach to conditionality can be contrasted with the more aggressive 'Washington consensus' approach adopted by other international donors.

\section{5 - ODA in Tanzania}

\section{$5 a-$ The Literature}

One of the most comprehensive studies on ODA to Tanzania is that by Bigsten et al. (2001) published in a major World Bank study which included ten country case studies in all. It is significant that, for a study published in final form in 2001, the most recent data in the main series which are analysed is for 1996, indicating the lead time for this type of major study. For our purposes Bigsten et al.'s study is mainly of historical interest, however its main database is largely the same as that confronting the authors of the Helleiner Report (Helleiner et al., 1995). In this same time period Wangwe produced a comprehensive overview of 'The Management of Foreign Aid in Tanzania', prior to the development of the principles of the Paris Declaration, which highlighted the issues of aid ownership, joint ownership of aid, capacity building, complete resource, budgeting, policy direction, aid coordination, aid conditionality, and dealing with corruption (Wangwe, 1997). It is salutary to find that essentially the same set of issues could have been highlighted in a follow-up paper in $\mathbf{2 0 1 5}$ without any sense of re-inventing the wheel - the same issues are still at the forefront of the discourse around ODA, both globally and more specifically in the Tanzanian context. Many of the issues are revisited constructively in a paper by Helleiner produced early in the new millennium (Helleiner, 2001). Another paper presented to the conference for which Wangwe's 1997 paper was prepared was by Wangwe and Ndulu (1997), giving a brief and authoritative overview of Tanzanian economic development in the decade following the adoption of the 1986 Economic Recovery Programme. In the context of ODA the sections of this joint paper dealing with international debt and with the relationship between economic growth and poverty reduction are of particular interest.

In 2005 the Tanzanian 'Independent Monitoring Group' produced an evaluative review of ODA relationships in Tanzania (URT, 2005a; Killick, 2004). A summary of its broad conclusions appears in Box 3. The broadly positive outcomes shown in Box 3 are from an independent evaluation, undertaken within Tanzania by an international group of experts, ${ }^{15}$ and providing an invaluable source which can be compared with external evaluations undertaken by the donor community. However, it also has to be recognised that this 2005 evaluation was undertaken ten years ago. There are two particular areas in which a comparison of comments in this 2005 Tanzanian evaluation with the perspectives of the donor community is of interest. The first is that of the Sector Wide Approach - which is described as an "approach (SWAp) to aid organisation and delivery which became popular in the donor community in the mid 1990s [and] was a response to the fragmentation, and perceived limited effectiveness of aid" (URT, 2005a: 22). The main problem identified with 
the SWAp by the evaluation group was that the "vested interests of sectors in collusion with DPs [ODA donors) leads to exaggeration of mistrust on MoF [Ministry of Finance] and engagement of lobbies to delay changing the system for the better. This observation is consistent with the observation made by Berke (2002) in the context of embedding sector programmes to the PRS process" (URT, 2005a: 24). The second area concerns the definition of 'harmonisation', a key concept within the Paris Declaration: "It appears that DPG [the Tanzanian Development Partners Group] does not have a working definition of what it means by harmonisation" (URT, 2005a: 28) and "some donors continue to carry out practices, which are not consistent with the spirit of TAS [Tanzania Assistance Strategy], Rome Declaration, [and] developments in harmonisation and alignment agreements at OECD/DAC level." (URT, 2005a: 29).

\section{Box 3 - Summary of the findings of the 2005 Report of the Independent Monitoring Group}

- GoT leadership and ownership has been strengthened;

- The formulation of national priorities and processes in Tanzania Mainland and Zanzibar are not yet harmonised;

- Reasonably good progress has been made in rationalisation and harmonisation and alignment of processes with a view to reducing transaction costs;

- Public resource management has improved considerably;

- Participation by all stakeholders in policy dialogue has been broadened and is becoming more institutionalised;

- GoT needs to be more assertive in stating its preferred forms of aid modality. The GoT has expressed a preference for General Budget Support (GBS) as an aid modality;

- Concerns have been expressed about the risks of deepening aid dependence;

- The TA [technical assistance] modality of aid has continued to be the most challenging in terms of continuing to be supply driven, tied procurement and little built in capacity building.

Source: Derived from URT, 2005a.

Nyoni (1997) undertook detailed analysis of economic management dimension of ODA impact on a number of Tanzanian macroeconomic variables. His summary of the conclusions arising from this study are: "The estimated model results suggest that foreign aid inflows, openness of the economy and devaluation of the local currency lead to depreciation of the real exchange rate, while government expenditure tends to appreciate the real exchange rate. The study recommends that the correct policy response to the influx of foreign aid is to direct the aid to domestic productive investment in order to induce a positive supply response. The government should also reduce its expenditure and enhance economic liberalization." There are limitations and surprises associated with this careful study. The data set used for the analysis ends in 1993, so there is the possibility that extending this type of analysis to more recent periods would affect the results. The usual presumption has been that significant ODA inflows tend to appreciate the exchange rate in the 'Dutch Disease' process - but Nyoni's study comes to the opposite conclusion because, it appears, the exchange rate over the period studied was 'administered'. The advent of a liberalised exchange rate regime might change the economic relationships in later periods. 
A report prepared by ActionAid (UK) in 2004 focussed on key issues associated with ODA conditionality as applied to the development of the water supply system in Dar es Salaam, and specifically to pressure applied by donors for privatisation of the system. In particular it highlighted contradictions between the poverty reduction objectives of social infrastructure development and the cost recovery and other financial objectives of privatised systems. However, Tripp (2012: 20) reports that this attempt at privatisation proved to be unsuccessful because "the larger infrastructure enterprises [including Dar es Salaam Water Supply and Sanitation] proved more challenging and were unable to become financially sustainable through public-private partnerships. With the exception of Tanzania International Container Terminal Services (TICTS), they all reverted to public control." This case illustrates the limitations of some types of donor conditionality, suggesting that even from a pragmatic viewpoint it has not always been realistic.

\section{5b-The Tanzanian Assistance Strategy and Public Financial Management Reform}

The Tanzanian Joint Assistance Strategy (JAST) is the successor to the Tanzanian Assistance Strategy (TAS) which was launched in 2002 (URT, 2004; URT, 2006a). In 2006 the African Development Bank produced a background document which provides a useful summary of the history and processes involved in the establishment of the TAS and its evolution into the JAST (AfDB, 2006). This African Development Bank document also provides an invaluable commentary charting the way in which the Tanzanian government interacted with the donor community in attempting to apply the principles of the Paris Declaration (see Box 2). Another African Development Bank document provides more insights into the process of implementing the JAST (AfDB, 2007). A Memorandum of Understanding committing the Tanzanian government and its 'development partners' to the 2006 JAST (and to the principles of the Paris Declaration was signed by representatives of Tanzania, the African Development Bank, Belgium, Canada, Denmark, the European Commission, Finland, France, Germany, Ireland, Japan, The Netherlands, Norway, Spain, Sweden, Switzerland, the United Kingdom, the United Nations, the United States and the World Bank (URT, 2006b). This Memorandum of Understanding at least provides a diplomatic overlay for the implementation of the JAST and the Paris Declaration.

The JAST has a monitoring framework which reflects five main objectives: i. Strengthening national ownership and Government leadership of the development process; ii. Aligning Development Partner support to Government priorities, systems, structures and procedures; iii. Harmonising Government and Development Partner processes; iv. Managing resources for achieving development results, in particular on Tanzania's National Strategy for Growth and Reduction of Poverty (MKUKUTA/MKUZA); and v. Strengthening domestic and mutual accountability (URT, 2007: 5). It is clear that these objectives closely reflect the principles of the Paris Declaration. The monitoring system set out in the 2007 document is very detailed, but it is not clear to what extent it has been followed up consistently in subsequent reports and evaluation studies.

One of the major Paris Declaration objectives is the achievement of reforms aimed at improving the quality of public finance management (PFM), including tracking expenditure and auditing. A report from the Tanzanian Ministry of Finance sets out a range of detailed 
targets and achievements from what is referred to as the PFMRP (Public Finance Management Reform Programme) (URT, 2009). The principal aims of the PFMRP have been to maintain aggregate fiscal discipline and accountability, to allocate resources in accordance with Government priorities, and to ensure efficient delivery of service support. Parts of the PFMRP monitoring have been sub-contracted to international consultants, and a 2013 report by Oxford Policy Management (OPM) was funded by the Swedish aid agency (OPM, 2013). This OPM report is exceptionally detailed and, although it specifies shortcomings in the implementation of the PFMRP, it also reports substantial progress in the achievement of targets. These targets are, of course, very relevant to the achievement of improved governance and to the control of corruption. There is only very limited discussion of anti-corruption measures (OPM, 2013: 24) but, as in other parts of the report, there are indications of positive progress being achieved in implementation and in the achievement of targets.

An extract from the Tanzanian government's 2009 PFM performance report provides some telling information about the state of the systems in place at the time:

"Public access to fiscal information, both in the budget presentation and execution phases is good. Fiscal information in both budget documentation and execution reports are provided through several means, including the media and some government websites. However, the coverage and details of information are limited in the budget execution phase. For example, the actual composition of the MDAs' [Ministries, Departments and Agencies] budgets are not published in the course of the year. These details are also excluded from the government final accounts, as the final accounts and government financial statements are very brief, only summarizing government transactions. The lack of an internationally-accepted functional classification in the budget, as well as the presentation of recurrent and development expenditures in different formats (very detailed for recurrent expenditures and very brief for development expenditures) reduce the value of the budget documentation. There are unreported expenditures in the budget and accounting systems, and some limited donor-financed operations do not pass through government systems. More importantly, the expenditures of AGAs [Autonomous Government Agencies] that are financed from earmarked revenues as well as from the government budget are not reported in a timely manner and in a classification compatible with the government and MDAs' budgets" (URT, 2010b: 1-2).

It is clear from this report that there have been distinct limitations in the quality of accessible information about the government's budget, in the identification of unreported expenditures, and in donor finance which by-passes government systems. ${ }^{16}$ Reporting of financial outcomes were delayed and were not in the required formats. Although this gives reasons for concern about the standard of PFM, it is notable that these strictures appear in a document prepared and published by the Ministry of Finance.

A more recent PFM performance report, prepared by the Brussels-based consultancy Analysis for Economic Decisions - ADE and funded by the EU, discusses achievements and limitations of PFM reform in a similar vein to the 2009 report (URT, 2013). 
"This repeat PEFA assessment reveals significant progress in strengthening PFM systems, largely reflecting the impact of the Public Finance Management Reform Programme (PFMRP). Reforms are still on-going, so PFM systems should continue to strengthen. Two major problem areas remain that impact directly on the credibility of the budget. The first major problem area is weaknesses in non-salary internal control systems. ...... The second major problem area is the fiscal risk to the budget posed by some public enterprises" (URT, 2013: i).

The overall conclusion of this 2013 report can be represented by another quotation: "Progress has definitely been made in PFM reform over the last few years and is continuing to be made. People may be disappointed that the number of improvements has not been higher in terms of PEFA ratings. However, PFM reform is a long process" (URT, 2013: xvii). The inadequately reported expenditure mentioned as a problem in the 2009 report comprise "well over 10 percent of expenditure" in the more recent, and more detailed, 2013 report (URT, 2013: iii), suggesting that a little more information has become available concerning these shortcomings.

\section{6 - Conclusions}

Tanzania, Ghana and Uganda have been receiving very significant amounts of ODA in recent years, with Tanzania being the principal 'beneficiary'. The ratio of ODA to GNI has been falling in all three countries, mainly because of the sustained high rate of economic growth which have been experienced. For these countries the high ratio of ODA to government expenditure has been particularly notable, with ODA funding a high proportion of nonrecurrent or 'development' expenditure. In the case of Tanzania ODA still accounted for about 70 percent of government expenditure in 2012, with budget support being an important part of this.

There have been notable changes to the 'aid architecture' in the last two decades. One of the notable recent developments has been the rise of 'umbrella organisations', such as GAVI, the Global Fund, and HIROs, which have been supporting medical/health programmes with funding from both bilateral and multilateral ODA institutions, from major private foundations, traditional and 'new' NGOs, the pharmaceutical industry and from international private commercial bodies. In recent years this 'umbrella funding' has contributed funds equivalent to about 5 to 10 percent of ODA. This 'umbrella funding' is one example of what has been referred to as 'blending', where international funding of development programmes is assembled from a range of ODA institutions as well as the financial sector, with no single institution providing a dominant part of the funding. In this context the role of ODA may be partly of a 'catalytic' nature, with the ODA impact being direct (through ODA funding) and indirect (through a 'leveraging' function associated with the non-ODA funding).

A major question is still that of whether ODA has had a positive impact on economic growth. Economists can still not reach a consensus on this issue, although more recent robust international quantitative studies are pointing towards the conclusion that ODA has a small but significant positive effect. There is still a dearth of detailed country studies which assess the impact of ODA on economic growth in the context of modern growth theory. However, 
there is some evidence that the role of ODA in sub-Saharan Africa has had a positive impact on growth through its leverage effect on economic reform and on its support of programmes designed to enhance governance and the policy environment. The research question has usually been in the form of 'does ODA have a positive effect on economic growth?' rather than the alternative of 'what would the recipient countries' economic position have been in the absence of ODA?'. This alternative represents the 'counterfactual' question.

Over the last two decades an increasing proportion of ODA has been committed to poverty reduction in a 'direct', rather than an 'indirect', fashion. 'Direct' commitments to poverty reduction are associated with social infrastructure programmes (e.g. health, education, water and sanitation), while 'indirect' commitments are associated with economic infrastructure (e.g. transportation and energy) and production (e.g. agricultural development and credit). 'Indirect' commitments should impact poverty reduction through the connection between economic growth and poverty reduction - with 'income poverty' being targeted in particular. 'Direct' commitments, such as those identified above, are more likely to impact broader definitions of poverty, such as those embodied in multidimensional indices, the HPI, and the HDI. In the case of Tanzania there has been a 'flat-lining' of poverty measures over the first decade of this millennium - poverty has appeared to represent an intractable problem. However, in the cases of Ghana and Uganda there have been notable reductions in the levels of poverty as measured by the conventional indices.

Budget support (BS) was an increasing feature of ODA commitments, particularly after the international deliberations surrounding the Paris Declaration. Evaluations of ODA, and of BS in particular, have indicated significant success in achieving acceleration of development programmes through BS. The Tanzanian government has a preference for the BS form of ODA, but donors have been less enthusiastic particularly due to the links between BS, a paucity of robust financial tracking and accounting, and corruption. The recent decision of the UK DFID to bring its BS provision to Tanzania to an end, in contradiction to the recommendations of a number of evaluations, is perhaps a sign of impatience with the slow speed of achieving substantial results from anti-corruption measures and public finance reform. Most of the evaluation studies have been very conscious of the inevitability of this 'slow speed', which has affected the reform of donor institution practices as much as those of recipient countries such as Tanzania.

This 'slow speed' of reform also affects the implementation of the principles of the Paris Declaration (PD). The PD heralded significant changes to the relationship between donors and recipients - the 'development partners'. Evaluations tend to suggest that 'alignment' with the principles of the PD has been more difficult to achieve within the donor community than in recipients such as Tanzania, Ghana and Uganda. The high profile of the Tanzania Assistance Strategy (both the TAS and its successor JAST) is notable, as is the ready availability in the public domain of reports by the Tanzanian 'Development Partners Group' and of the Independent Monitoring Group. The literature refers to steady progress in Tanzania in achieving improvements to public finance management and to addressing the corruption issue, and it must be hoped that future responses from the donor community will be supportive of this steady progress. 


\section{References}

Action Aid (2004) Turning off the taps: Donor conditionality and water privatisation in Dar es Salaam, Tanzania. London: Action Aid - accessible from www.actionaid.org.uk/policy-and-research/research-and-publications/

Action Aid (2005) Real Aid: An Agenda for Making Aid Work. London: Action Aid - accessible from http://www.un-ngls.org/orf/cso/cso9/real-aid.pdf

Action Aid (2011) Real Aid 3: Ending Aid Dependency. London: Action Aid - accessible from www.actionaid.org.uk/policy-and-research/research-and-publications/

AfDB (2006) Tanzania Joint Assistance Strategy Review Of The Harmonization Process In Five Countries. Tunis: African Development Bank - accessible from www.afdb.org

AfDB (2007) Tanzania: Joint Assistance Strategy and Joint Programme Document - Cover Note. Tunis: African Development Bank - accessible from www.afdb.org

Africa Progress Panel (2014) African Progress Report 2014. Geneva: Africa Progress Panel Accessible at http://africaprogresspanel.org/homepage/

Arndt, C., Jones, S. and Tarp, F. (2015) Assessing Foreign Aid's Long-Run Contribution to Growth in Development. World Development. 69: 6-18.

Barkan, J. (2009) Rethinking Budget Support for Africa. In Joseph, R. and Gillies, A. (eds.) Smart Aid for African Development. Boulder CO: Lynne Rienner Publishers: 67-85.

BBC (2001) Tanzania 'needs costly radar system'. BBC News website $21^{\text {st }}$ December $2001-$ accessible from www.bbc.co.uk/news

Berke, C. (2002) Embedding SPs in the PRSP-Process A Framework for Discussion Desk-based Background Paper. Commissioned by KfW for the Task Team "Sector Programs" of the Strategic Partnership with Africa (SPA) - accessible as swap151 from www.swisstph.ch/

Betts, J. and Wood, B. (2013) The Paris Declaration Evaluation: Process and Methods. Canadian Journal of Program Evaluation. 27 (3): 69-102.

Bigsten, A., Mutalemwa, D., Tsikata, Y. and Wangwe, S. (2001) Tanzania. In Devarajan, S, Dollar, D. and Holmgren, T. (eds.) Aid and Reform in Africa. Washington DC: World Bank.

Carey, R. (2005) Real or Phantom Aid. DAC News June-August. Paris: Organisation for Economic Cooperation and Development - accessible from http://www.oecd.org/dac/

Chang, H-J. 2014. Taking production seriously: Why we need a 'productionist' development discourse. $20^{\text {th }}$ Bradford Development Lecture - accessible from www.bradford.ac.uk/ssis/bcid/bdl/

Clemens, M., Radelet, S., Bhavnani, R. and Bazzi, S. (2012) Counting Chickens when they Hatch: Timing and the Effects of Aid on Growth. The Economic Journal, 122(561): 590-617.

Daily Mail (2014) Tory fury as increasing aid budget becomes law: Conservative MPs ordered to vote in favour of proposed Bill. Daily Mail $12^{\text {th }}$ September $2014-$ accessible from www.dailymail.co.uk

Devarajan, S. (2013) Africa's Statistical Tragedy. Review of Income and Wealth. Series 59, October: S9-S15.

DFID (2011a) Bilateral Aid Review. London: Department for International Development downloaded from www.dfid.gov.uk on 10th February 2012. 
DFID (2011b) Bilateral Aid Review: Technical Report. London: Department for International Development - downloaded from www.dfid.gov.uk on 10th February 2012.

DFID (2011c) Multilateral Aid Review. London: Department for International Development downloaded from www.dfid.gov.uk on 28th February 2013.

DFID (2014) Operational Plan 2011-2016 DFID Tanzania (Updated December 2014). London: Department for International Development.

d-portal.org (2014) Development Portal - accessible from http://d-portal.org/

Easterly, W. (2003) Can Foreign Aid Buy Growth? Journal of Economic Perspectives. 17 (3): 23-48.

Easterly, W. (2006) The White man's Burden: Why the West's Efforts to Aid the Rest have Done so Much III and so Little Good. London: Penguin Books.

Easterly, W. Levine, R. and Roodman, D. (2004) Aid, Policies, and Growth: Comment American Economic Review. 94 (3): 774-780.

FT. (2014) David Cameron's foreign aid pledge to cost extra $f 1 b n$. Financial Times $4^{\text {th }}$ December 2014 - accessible from www.ft.com

Gomanee, K., Girma, S. and Morrissey, O. (2005) Aid and Growth in Sub-Saharan Africa: Accounting for Transmission Mechanisms. Journal of International Development. 17: 1055-1075.

GFI (2014) Hiding in Plain Sight. downloadable from the Global Financial Integrity website at http://www.gfintegrity.org/reports/

Global Partnership. (2013) Guide to the Monitoring Framework of the Global Partnership Final Version July 2013. Geneva: Global Partnership for Effective Development Cooperation - accessible from www.effectivecooperation.org

Griffin, K. (1970) Foreign Capital, Domestic Savings and Economic Development. Bulletin of the Oxford University Institute of Economics \& Statistics. (32) 2: 99-112.

GSS (2010) Rebasing of Ghana's National Accounts to Reference Year 2006. Accra: Ghana Statistical Service.

Guardian (2006) Fraud Office inquiry into BAE Tanzania deal. Monday $13^{\text {th }}$ November accessible from theguardian.com

Guardian (2010) New bribery law puts overseas payments under scrutiny. Monday $12^{\text {th }}$ April 2010 - accessible from theguardian.com

Guardian (2014) UK and international donors suspend Tanzania aid after corruption claims. Monday 13th October - accessible from theguardian.com

Helleiner, G. (2001) Local Ownership and Donor Performance Monitoring: New Aid Relationships in Tanzania? Department of Economics and Munk Centre for International Studies, University of Toronto - accessible from http://www.swisstph.ch/

Helleiner, G. K. et al ..... (1995) Report of the Group of Independent Advisers on Development Cooperation Issues Between Tanzania and Its Aid Donors. Copenhagen: Royal Danish Ministry of Foreign Affairs. Reprinted in Wangwe, S. M. (ed.) (2002) NEPAD at Country Level: Changing Aid Relationships in Tanzania. Dar es Salaam: Mkuki na Nyota Publishers.

House of Commons (2013a) The $0.7 \%$ aid target. London: House of Common - accessible from www.parliament.uk 
House of Commons (2013b) Multilateral Aid Review: Fourth Report of Session 2013-14 (Volumes 1 and 2). London: The Stationery Office -

http://www.parliament.uk/business/committees/committees-a-z/commons-

select/international-development-committee/inquiries/parliament-

2010/multilateral-aid-review/

Hyden, G. (2005) Reaching the Poor: The Need for a New Donor Strategy. In Tribe, M., Thoburn, J. and Palmer-Jones, R. (eds.) Development Economies and Social Justice: Essays in Honour of lan Livingstone. Aldershot: Ashgate: 13-26.

ICAI (2012) The Management of UK Budget Support Operations. London: Independent Commission for Aid Impact.

ICAI (2014) DFID's Approach to Anti-Corruption and its Impact on the Poor. London: Independent Commission on Aid Impact - accessible from www.icai.independent.gov.uk

Irish Aid/DFID (2010) Joint Irish Aid and DFID Country Programme Evaluation: Tanzania 2004/05-2009-10. ITAD with Fiscus Ltd and Verulam Associates Ltd - Thornton, P., Dyer, K., Lawson, A., Olney, G., Olsen, H. and Pennarz, J. Dublin and London: Irish Aid and DFID.

Jerven, M. (2012) Poor Numbers: How We Are Misled by African Development Statistics and What to Do about It. Ithaca NY: Cornell University Press.

Jerven, M. (2013) Comparability of GDP Estimates in sub-Saharan Africa: The Effect of Revisions in Sources and Methods Since Structural Adjustment. Review of Income and Wealth. Series 59, October: S16-S36.

Jerven, M. (2014) Measuring African development: past and present. Introduction to the Special Issue. Canadian Journal of Development Studies. 35 (1): 1-8.

Kaberuka, D. (2011) Development and Aid in Africa: What have we learned from the past 50 years? Chapter 3 in OECD DAC. Development Co-operation Report 2011. Paris: OECD DAC - downloadable from the OECD website: www.oecd.org

Kahyarara, G. (2014) Aid and environment in Africa: The case of Tanzania. UNU WIDER Working Paper 2014/077. Helsinki: United Nations University - accessible from www.wider.unu.edu/publications

Kharas, H. (2007) Trends and Issues in Development Aid. Working Paper 1, Wolfensohn Center for Development. Washington: Brookings Institution - downloadable from www.brookings.edu/wolfensohncenter

Killick, T. (2004) Monitoring Partnership-based Aid Relationships. Development Policy Review. 22 (2): 229-234.

Lof, M., Mekasha, T. J. and Tarp, F. (2013) Aid and income: Another time-series perspective. World Development. 69: 19-30.

McGillivray, M., Feeny, S., Hermes, N. and Lensink, R. (2006) Controversies over the impact of development aid: it works; it doesn't; it can, but that depends.... Journal of International Development. 18 (7): 1031-1050.

McMillan, M., Rodrik, D. and Verduzco, I. (2014) Globalization, Structural Change, and Productivity Growth, with an Update on Africa. World Development. 63: 11-32.

Ministry of Justice (2011) Bribery Act 2010 - Guidance. London: Ministry of Justice accessible from www.justice.gov.uk/downloads/legislation/

Morgenstern, O. (1963) On the Accuracy of Economic Observations (2 ${ }^{\text {nd }}$ ed.). Princeton NJ: Princeton University Press. 
Mosley, P. (1980) Aid, Savings and Growth Revisited. Oxford Bulletin of Economics and Statistics. 42 (2): 79-95.

NAO (2008) Department for International Development: Providing budget support to developing countries. London: National Audit Office.

Nyoni, T. S. (1997) Foreign Aid and Economic Performance in Tanzania. AERC Research Paper 61. Nairobi: African Economic Research Consortium.

OECD (2014) OECD Foreign Bribery Report: An Analysis of the Crime of Bribery of Foreign Public Officials. Paris: Organisation for Economic Cooperation and Development accessible from www.oecd-ilibrary.org/governance/

OECD DAC (2005 and 2008) The Paris Declaration on Aid Effectiveness - and The Accra Agenda for Action. Paris: Organisation for Economic Cooperation and Development downloadable from the OECD website: http://www.oecd.org/dataoecd/11/41/34428351.pdf

OECD DAC (2011) Busan Partnership for Effective Development Co-operation. Paris: Organisation for Economic Cooperation and Development - downloadable from the OECD website: http://www.oecd.org/dac/aideffectiveness/49650173.pdf

OECD DAC (2014a) Statistics - accessible from http://www.oecd.org/dac/stats/

OECD DAC (2014b) DAC Glossary of Key Terms and Concepts. Paris: Organisation for Economic Cooperation and Development - accessible from http://www.oecd.org/dac/dac-glossary.htm\#ODF

OECD DAC (2015a) The High Level Fora on Aid Effectiveness: A History. Paris: Organisation for Economic Cooperation and Development - accessible from http://www.oecd.org/dac/effectiveness/thehighlevelforaonaideffectivenessahistory. htm

OECD DAC (2015b) Evaluation of development programmes - accessible from www.oecd.org/development/evaluation/

OPM (2013) Tanzania Public Finance Management Reform Programme Phase III Completion Report. Report prepared for Sida Tanzania and Ministry of Finance of the Government of Tanzania. Oxford: Oxford Policy Management - accessible from www.mof.go.tz/mofdocs/

Rajan, R. G. and Subramanian, A. (2008) Aid and Growth: What Does the Cross-Country Evidence Really Show? Review of Economics and Statistics 90 (4): 643-665.

Rodrik, D. (2014) An African Growth Miracle?. Working Paper 20188. Cambridge MA: National Bureau of Economic Research - accessible from www.nber

Romer, P. (1994) The Origins of Endogenous Growth Journal of Economic Perspectives 8 (1) 3-22.

Rotberg, R. I. (2007) Africa's Successes: Evaluating Accomplishment. Program on Intrastate Conflict Report Series, Belfer Center for Science and International Affairs - John F. Kennedy School of Government. Cambridge MA: Harvard University - accessible from www.belfercenter.org/project/52/intrastate_conflict_program.html

Selbervik, H. (1999) Aid and conditionality - The role of the bilateral donor: A case study of Norwegian-Tanzanian aid relationship. A Report submitted to the Norwegian Ministry of Foreign Affairs by the Chr. Michelsen Institute. Oslo: NORAD downloadable from www.norad.no

Severino, J-M., and Ray, O. (2009) The End of ODA: Death and Rebirth of a Global Public Policy. Working Paper No. 167. Washington: Center for Global Development downloadable from: www.cgdev.org 
Severino, J-M. and Ray, O. (2010) The End of ODA (II): The Birth of Hypercollective Action. CGD Working Paper 218, Washington, D.C.: Center for Global Development downloadable from: www.cgdev.org

Severino, J-M. (2011) The Resurrection of Aid. Chapter 9 in the OECD-DAC Annual Report for 2011. Paris: Organisation for Economic Cooperation and Development Development Assistance Committee: 121-133 - accessible from www.oecd.org/dac/

TI (2015) Corruption Perceptions Index. Berlin: Transparency International - accessible from www.transparency.org/research/cpi/overview

Tribe, M. (2013) Aid and Development: Issues and Reflections. Discussion Paper 13-09 Department of Economics, University of Strathclyde May - downloadable from http://www.strath.ac.uk/economics/departmentalresearch/discussionpapers/

Tribe, M. and Wanambi, N. (2003) Development Expenditure Management in Uganda. In Potts, D., Ryan, P. and Toner, A. (eds.). Development Planning and Poverty Reduction. London: Palgrave Macmillan: 148-163.

Tripp, A. M. (2012) Donor Assistance and Political Reform in Tanzania. UNU WIDER Working Paper No. 2012/37. Helsinki: United Nations University - accessible from www.wider.unu.edu/publications

UNDP (2015) Human Development Reports. New York: United Nations Development Programme - all reports available online from www.hdr.undp.org/en/reports

URT (2004) Tanzania Assistance Strategy Annual Implementation Report 2003/04. Dar es Salaam: Ministry of Finance, United Republic of Tanzania - accessible from www.mof.go.tz/mofdocs/external/tas.doc

URT (2005a) Enhancing Aid Relationships in Tanzania: Report of the Independent Monitoring Group to the Government of Tanzania and the Development Partners Group - 2005. Dar es Salaam: Ministry of Finance and the Economic and Social Research Foundation - accessed from www.jica.go.jp/cdstudy/library/ on $11^{\text {th }}$ April 2015 and accessible from www.mof.go.tz/

URT (2005b) National Strategy for Growth and Reduction of Poverty (NSGRP). Dar es Salaam: Vice President's Office - $\quad$ accessible from www.imf.org/external/pubs/ft/scr/2006/cr06142.pdf

URT (2006a) Joint Assistance Strategy for Tanzania. Dar es Salaam: Ministry of Finance downloaded from www.mof.go.tz/mofdocs 16th May 2014

URT (2006b) Memorandum of Understanding on the Joint Assistance Strategy for Tanzania (JAST) between the Government of the United Republic of Tanzania and Development Partners. Dar es Salaam: Government of the United Republic of Tanzania - accessible from www.tzdpg.or.tz/fileadmin/documents/dpg_internal/

URT (2007) Joint Assistance Strategy for Tanzania (JAST): Action Plan and Monitoring Framework Working Document. Dar es Salaam: Ministry of Finance, United Republic of Tanzania - accessible from

www.tzdpg.or.tz/fileadmin/documents/dpg_internal/dpg_main/for_new_dpg_mem bers/JAST_Action_Plan_and_Monitoring_Framework_working_document_2007_01.doc

URT (2009) PFMRP Annual Progress Report 2008-2009. Dar es Salaam: Ministry of Finance and Economic Affairs - accessible from www.mof.go.tz

URT (2010a) National Strategy for Growth and Reduction of Poverty II (NSGRP II). Dar es Salaam: Ministry of Finance - accessible from www.mof.go.tz 
URT (2010b) 2009 Public Financial Management Performance Report on Mainland Tanzania. Dar es Salaam: Ministry of Finance - accessible from www.mof.go.tz/mofdocs/PFMRP/PEFA/

URT (2013) Public Expenditure and Financial Accountability (PEFA) Assessment Mainland Tanzania (Central Government) - September 2013. Dar es Salaam: Ministry of Finance and Economic Affairs - accessible from www.mof.go.tz/mofdocs/PFMRP/PEFA/

URT (2014) Press Release on Highlights of the Revised GDP Estimates for Tanzania Mainland. Dar es Salaam: National Bureau of Statistics - downloaded from http://www.nbs.go.tz/nbs/ 30 ${ }^{\text {th }}$ November 2014.

Viergever, R. F. (2011) Aid Alignment for Global Health Research. Health Research Policy Systems. $\quad 9$ (12) - accessible from http://www.health-policysystems.com/content/pdf/1478-4505-9-12.pdf

Wangwe, S. M. (1997) The Management of Foreign Aid in Tanzania. ESRF Discussion Paper No. 15. Dar es Salaam: Economic and Social Research Foundation.

Wangwe, S. M. (ed.) (2002) NEPAD at Country Level: Changing Aid Relationships in Tanzania. Dar es Salaam: Mkuki na Nyota Publishers.

Wangwe, S. M. and Ndulu, B. J. (1997) Managing Tanzania's Economy in Transition to Sustained Development. ESRF Discussion Paper No. 14. Dar es Salaam: Economic and Social Research Foundation.

Wood, B. and Betts, J. (2013) Results of the Paris Declaration Evaluation. Canadian Journal of Program Evaluation. 27 (3): 103-128.

Wood, B., Betts, J., Etta, F., Gayfer, J., Kabell, D., Ngwira, N., Sagasti, F. and Samaranayake, F. (2011) The Evaluation of the Paris Declaration - Phase 2: Final Report. Copenhagen: Danish Institute for International Studies - accessible from www.oecd.org/dac/evaluationnetwork/pde

World Bank (2002) Poverty Reduction Strategy Papers Sourcebook Washington, DC: World Bank - accessible from http://go.worldbank.org/3I8LYLXO80

World Bank (2011) Country Assistance Strategy for the United Republic of Tanzania for the period FY 2012-2015. Washington DC: International Development Association, International Finance Corporation and Multilateral Investment Guarantee Agency accessible from www-wds.worldbank.org/external/

World Bank (2014a) World Development Indicators 2014. Accessed from UK Data Service at http://discover.ukdataservice.ac.uk

World Bank (2014b) Poverty Reduction Strategy Papers Washington DC: World Bank accessible from http://go.worldbank.org/CSTQBOF730

World Bank (2015) Corruption and Economic Development. Washington DC: World Bank accessible from

www1.worldbank.org/publicsector/anticorrupt/corruptn/cor02.htm 


\title{
Endnotes
}

\begin{abstract}
${ }^{1}$ Honorary Lecturer, Department of Economics, University of Strathclyde, Glasgow, UK
${ }^{2}$ The higher level of GDP for Ghana is partly explained by the revision of Ghanaian GDP statistics which occurred in 2010 (GSS, 2010). Prior to 2010 the old series was based on the 1968 UN SNA system and this was replaced by the 1993 UN SNA as a basis for the new GDP series, resulting in a 60.3 percent increase. The process of updating GDP statistics across sub-Saharan African countries, applying more recent UN SNA approaches, is a constant one. The Tanzanian National Bureau of Statistics has revised its GDP statistics several times in recent years, the most recent revision having been released in 2014 (URT, 2014). The main problem relating to the revision of national income statistics relates to whether the resulting time series permit a robust view of single country growth rates over long periods and to whether inter-country comparisons are realistic. Inter-country comparisons of GDP levels are always going to be subject to the assumption that the statistical methodologies involved permit realistic comparisons (Devarajan, 2013; Jerven, 2012, 2013, 2014; Morgenstern, 1963).

${ }^{3}$ Using proportions (rather than current price values) avoids the problems associated with variations in the reliability of individual country price deflators and changes in international currency exchange rates. The basic data in this paper is expressed in constant prices sourced from both international and national sources.

${ }^{4}$ The USA is the largest ODA donor country internationally despite having one of the lowest ODA/GNI ratios, reflecting the high level of the US GNI.

${ }^{5}$ The Global Fund is a comparatively recently established 'umbrella' organisation which is mainly focussed on the health/medical sector and which has been characterised as representing the phenomenon of 'blending' which is cited later in the paper.

${ }^{6}$ In the notes to Table 4 the citation to official Tanzanian government publications refers to 'URT' - the United Republic of Tanzania. This title and acronym have been used throughout the paper.

${ }^{7}$ In the process of preparing this paper an attempt was made to include data on illicit financial flows, particularly relating to over-invoicing of imports and under-invoicing of exports (in other words 'transfer pricing'). The principal contemporary source for this data is the work of Global Financial Integrity (GFI) and a recent detailed study of a number of African countries (including Tanzania, Ghana and Uganda) breaks new ground in this respect (GFI, 2014). However, because the research focus of the GFI differs significantly from that of this paper the GFI data is not directly comparable with the financial flows as defined in this paper.

${ }^{8}$ Most accessible NGO aid statistics are based on reporting outflows from donor countries rather than inflows by recipient countries. In order to check the availability of data for NGO aid inflows to recipient countries the OXFAM research department was consulted, but happily at about the same time that this paper was being prepared a new data source became available, and this is included in Table 5 (d-portal.org, 2015).

${ }^{9}$ Richard Carey was formerly Deputy Director of the OECD DAC Secretariat. A document outlining a response by the UK DFID to this issue, mentioned by Carey, appears not to be available at the time of writing.
\end{abstract}


${ }^{10} \mathrm{GAVI}$ is the Global Alliance for Vaccination and Immunisation, the Global Fund is The Global Fund to Fight AIDS, Tuberculosis and Malaria and HIROs is the Heads of International Research Organisations (refer to Viergever, 2011).

${ }^{11}$ The definition of ODF given by the OECD is: "Used in measuring the inflow of resources to recipient countries: includes (a) bilateral ODA, (b) grants and concessional and nonconcessional development lending by multilateral financial institutions, and (c) Other Official Flows for development purposes (including refinancing loans) which have too low a grant element to qualify as ODA." (OECD DAC, 2014b).

${ }^{12}$ A good basic source for endogenous growth theory is Romer's seminal article in the Journal of Economic Perspectives (Romer, 1994). A study which points out the dearth of studies linking economic growth theory with the contribution of ODA to economic growth is that of Gomanee et al. (2005).

13 The PRSPs were mandatory conditions for the application of the HIPC debt relief programme, but have also been widely adopted globally as economic development planning documents (World Bank, 2014b).

${ }^{14}$ The HDI is a composite index which has changed slightly over time. It is based on three elements: i) life expectancy at birth, ii) the average of mean years of schooling and expected years of schooling, and ii) per capita income at PPP US\$. Refer to Technical Note 1 (UNDP HDR 2014 - UNDP, 2015). In many respects the HDI is conceptually the obverse of the HPI and MPI. The HDI, and many other measures of 'development' and of 'poverty', raises technical questions over the inclusion of averages and distributions in complex indicators. 'Improvements' in average levels (for example of the HDI) could conceivably be associated with changes in the distributions, with a deterioration for the lower parts of the distribution and an improvement for the upper parts of the distribution.

${ }^{15}$ To quote the IMG Report: "The IMG team comprised four persons: Prof. Samuel Wangwe (Chairperson), Mr. Dag Aarnes (Consultant/Senior Economist, Partner Assist Consulting AS), Prof. Haidari Amani (Executive Director of ESRF) and Dr. Alison Evans (Independent Consultant and Associate of ODI, London - who made her contributions through commenting and contributing to drafts at all stages of this work). In carrying out research for this work the team received contributions from Mr. Deo Mutalemwa, Ms Kate Dyer (on the Education sector) and Ms Moorine Lwakatare" (URT, 2005a: iii).

${ }^{16}$ The remarks in this 2010 Tanzanian government report (URT, 2010b), together with those in the 2005 report of the Independent Monitoring Group (URT, 2005a), echo suggestions made during a 1998-99 Ugandan review which was the basis for a publication by Tribe and Wanambi (2003). The essence of this disquiet is that the Sector Wide approach lends itself to collusive attempts by sector specialists in, or funded by, donor institutions together with colleagues in recipient line ministries to bypass established recipient financial and planning procedures. This can lead to financial systems in Ministries of Finance being starved of financial information about the commitment and use of funds. This type of activity can account for the type of accounting and auditing problems referred to by both the 2005 and the 2010 reports. 